\title{
ESCRAVOS MARINHEIROS, SENHORES E LOCADORES \\ LEIS POMBALINAS, FAINA MARÍTIMA \\ E ECONOMIA MUNDIAL (1761-1810) ${ }^{1}$
}

\author{
Luiz Geraldo Silva ${ }^{2}$ \\ Priscila de Lima Souza ${ }^{3}$
}

\section{Reforma pombalina, alvarás e avisos}

As lutas multisseculares entre a primeira nobreza, também designada como de espada ou de nascimento, e a segunda nobreza, a nobreza togada - de origem sobretudo mercantil e nobilitada em decorrência de serviços prestados à monarquia -, produziram resultados que tanto escapavam do campo de visão daqueles rivais, como impactavam sobre as relações sociais e de poder atinentes a outros grupos da sociedade de tipo antigo. ${ }^{4}$

1 Versões preliminares deste artigo foram apresentadas em fevereiro e maio de 2019, respectivamente, no seminário "Petitions in the age of Atlantic Revolutions (c. 1760-c. 1840)" e no seminário do Laboratório de Estudos sobre o Brasil e o Sistema Mundial (LabMundi-USP). Os autores agradecem aos participantes por seus comentários e sugestões.

2 Doutor em História Social pela Universidade de São Paulo (USP) e professor titular do Departamento de História da Universidade Federal do Paraná (UFPR). Bolsista de produtividade em pesquisa do Conselho Nacional de Pesquisa e Desenvolvimento Tecnológico (CNPq), nível 1-D. gerter@terra.com.br.

3 Doutora em História Social pela Universidade de São Paulo (USP) e professora com vínculo temporário no Departamento de História da Universidade Federal do Paraná (UFPR). cila_lima@yahoo.com.br.

4 Norbert Elias, O processo civilizador: v. 1: uma história dos costumes, Rio de Janeiro: Jorge Zahar Editor, 1990, pp. 85-96; Nuno Gonçalo Monteiro, "Notas sobre nobreza, fidalguia e titulares nos finais do Antigo Regime", Ler História, n. 10 (1987), pp. 15-51. 
Um dos resultados desses embates se materializou num conjunto de alvarás e avisos publicados entre 1761 e 1800, o qual afetou diretamente as vidas de vários africanos e afrodescendentes escravos, livres e libertos, bem como de seus senhores e locadores. Como demonstraremos adiante, estes grupos, presentes sobretudo nas sociedades escravistas da América portuguesa, foram envolvidos de diferentes modos e em variados graus nas tensões decorrentes da aplicação daqueles alvarás e avisos, em consonância com suas respectivas ocupações ou funções sociais. Neste artigo, destacamos em particular os escravos marinheiros - fossem estes africanos ou "crioulos", isto é, nascidos na América -, os quais, embora constituíssem um grupo social de reduzido número, revelavam-se absolutamente vitais para a manutenção das conexões marítimas entre as distintas partes do império. ${ }^{5}$

Os alvarás e avisos publicados entre 1761 e 1800, bem conhecidos, aliás, pela historiografia, constituem um conjunto de seis textos legais. ${ }^{6} \mathrm{O}$ primeiro deles foi o alvará de 19 de setembro de 1761, cujo teor determinava que, a partir dos portos "da África, América e Ásia", não se pudesse "carregar, nem descarregar nestes Reinos de Portugal, e dos Algarves, Preto ou Preta alguma"; o alvará também determinava que "quaisquer pessoas" que vendessem, comprassem ou retivessem

5 Luiz Geraldo Silva, A faina, a festa e o rito: uma etnografia histórica sobre as gentes do mar, Campinas: Papirus, 2001, pp. 150-198; Jaime Rodrigues, De costa a costa: escravos, marinheiros e intermediários do tráfico negreiro de Angola ao Rio de Janeiro (1780-1860), São Paulo: Companhia das Letras, 2005, pp. 159-185; Jaime Rodrigues, "Escravos, senhores e vida marítima no Atlântico: Portugal, África e América portuguesa, c. 1760-c. 1825", Almanack, n. 5 (2013), pp. 145-177.

6 Francisco Falcon e Fernando Antônio Novais, "A extinção da escravatura africana em Portugal no quadro da política econômica pombalina”, VI Simpósio dos Professores Universitários de História (São Paulo, 1973), pp. 416-421; Maria do Rosário Pimentel, Viagem ao fundo das consciências: a escravatura na época moderna, Lisboa: Colibri, 1995, pp. 167-194; Luiz Geraldo Silva, “Esperança de liberdade': interpretações populares da abolição ilustrada”, Revista de História, n. 144 (2001), pp. 107-149; Silvia Hunold Lara, Fragmentos setecentistas. escravidão, cultura e poder na América portuguesa, São Paulo: Companhia das Letras, 2007, pp. 126-172; Priscila de Lima, "De libertos a habilitados: interpretações populares dos alvarás antiescravistas na América portuguesa (1761-1810)" (Dissertação de Mestrado, Universidade Federal do Paraná, 2011); Cristina Nogueira da Silva e Keila Grinberg, "Soil free from Slaves: Slave Law in Late Eighteenth and Early Nineteenth-Century Portugal", Slavery \& Abolition, v. 32, n. 3 (2011), pp. 431-446; Rodrigues, "Escravos, senhores e vida marítima no Atlântico", pp. 145-177; Luiz Geraldo Silva e Priscila de Lima Souza, “'Sem a nota de libertos': mudanças nas petições de afrodescendentes livres da América portuguesa ao longo do século XVIII", El Taller de la Historia, v. 9, n. 9 (2017), pp. 28-56. 
escravos recém-introduzidos no reino fossem penalizadas nos mesmos termos dos que "fazem cárceres privados, e sujeitam a Cativeiro os Homens que são livres". Ao mesmo tempo, consagrava-se que, a partir de seis meses após a publicação da lei, os escravos que fossem introduzidos em Portugal ficassem "pelo benefício dela libertos, e forros, sem necessitarem de outra alguma Carta de manumissão, ou alforria, nem de nenhum outro despacho". Contudo, ao sublinhar que tais determinações não se referiam aos escravos "que já se acham nestes Reinos", os subscritores desse texto legal - o futuro marquês de Pombal e o próprio monarca, D. José I - deixavam claro que o alvará de setembro de 1761 longe estava de constituir uma peça "humanitária" ou "abolicionista". Tal ponto de vista é reiterado pela asserção conforme a qual seu conteúdo não deveria fornecer pretexto para que "desertem dos Meus Domínios Ultramarinos os Escravos que neles se acham”, razão pela qual todos os africanos e afrodescendentes livres e libertos que fossem daí por diante à parte europeia do império deveriam portar "Guias das respectivas Câmaras dos lugares donde saírem". ${ }^{7}$ O segundo desses textos legais foi o aviso de 2 de janeiro de 1767, o qual objetivava tão somente emendar o alvará precedente. Conforme o aviso, muitos senhores de escravos tinham interpretado erroneamente que o alvará de 1761 aplicava-se apenas aos "pretos e pretas", razão pela qual mantinham em cativeiro os "mulatos e mulatas". Assim, considerava-se, pois, que não era "justo que ficando os pais e mães, sendo pretos, livres e forros por benefício do mesmo Alvará, fiquem os filhos escravos". ${ }^{8}$

O terceiro texto legal - seguramente, o mais impactante de todos foi o alvará de 16 de janeiro de 1773. Este se inicia referindo-se ao alvará de 1761, dando, pois, a entender a clara conexão entre eles. O texto legal de 1773 destaca, em primeiro lugar, que, apesar de proibido o tráfico, a reprodução da escravidão seguia seu curso no reino, uma vez que "pessoas tão faltas de sentimentos de humanidade e de religião" davam lugar à reprodução natural do cativeiro por via de concubinatos. ${ }^{9}$ Seguia-se

7 Alvará, 19/09/1761, in Antônio Delgado da Silva, Collecção da Legislação Portugueza: v. 1: de 1750 a 1762 (Lisboa: Tipografia Maigrense, 1830), pp. 811-812.

8 Aviso, 02/01/1767, in Silva, Supplemento à Collecção de Legislação Portugueza: v. 2: de 1763 a 1790 (Lisboa: Tipografia de Luiz Correa da Cunha, 1844), pp. 128-129.

9 Alvará, 16/01/1773, in Silva, Collecção da Legislação Portugueza: v. 2: de 1763 a 1774 
daí, portanto, a determinação de os escravos "cuja escravidão vier das bisavós, fiquem livres e desembargados". Por sua vez, todos os escravos nascidos após a promulgação da lei estariam "inteiramente livres", mesmo "que as mães e avós hajam sido escravas". Ao mesmo tempo, o alvará de 1773 refere-se ao fato de que a escravidão, além de ferir os ideais de "humanidade" e "religião", causava perdas ao "Estado" por produzir "vassalos lesos, baldados e inúteis" para o exercício dos "ofícios públicos, para o comércio, para a agricultura e para os tratos e contratos de todas as espécies". Como decorrência dessa constatação, determina-se o fim da "Nota distintiva de Libertos". Estes, como se sabe, têm, em todas as sociedades escravistas, fossem estas do mundo antigo ou moderno, limitações, inabilitações e restrições ao usufruto de prerrogativas exclusivas aos indivíduos nascidos livres ou, no caso das cidades-estados da antiguidade, dos "cidadãos". ${ }^{10}$ Assim, a lei de 1773, ao determinar que os libertos se convertessem, daí por diante, em indivíduos "hábeis para todos os ofícios, honras e dignidades", tinha a imensa pretensão de denegar uma arraigada tradição ocidental. ${ }^{11}$

O quarto texto legal foi o aviso de 22 de fevereiro de 1776, o qual emendava o alvará de 1761 diante da incontornável realidade atinente ao emprego de marinheiros escravos na navegação de longo curso. O aviso inicia por reconhecer que "se tem embaraçado nos Portos da América" o emprego de "Escravos pretos, ou pardos com a obrigação de marinheiros" em decorrência do "receio" de aqueles "ficarem libertos". Assim, pois, o aviso de 1776 constituía uma garantia formal de "que todos os escravos marinheiros" que fossem "ao porto da Cidade de Lisboa, e mais portos deste Reino” não seriam compreendidos no alvará de 1761 . Bons conhecedores da matéria, os legisladores egressos da nobreza togada formulavam com clareza a quem pertenciam estes escravos: "aos donos dos Navios", aos “oficiais que nele andam embarcados" ou, ainda, a "quaisquer outras pessoas moradoras na América" que os quisessem

(Lisboa: Tipografia Maigrense, 1829), pp. 639-640.

10 Moses I. Finley, "Entre a escravatura e a liberdade", in Jacques Annequin, Monique Clavel-Lévêque e François Favory (orgs.), Formas de exploração do trabalho e relações sociais na Antiguidade Clássica (Lisboa: Estampa, 1978), pp. 96-100; Orlando Patterson, Slavery and Social Death: A Comparative Study, Cambridge: Harvard University Press, 1982, pp. 240-261.

11 Alvará, 16/01/1773, in Silva, Collecção... v. 2, pp. 639-640. 
"trazer ao ganho das Soldadas dos Navios de comércio". No entanto, para que o aviso se tornasse efetivo, fazia-se necessário matricular os marinheiros escravos nas equipagens, bem como declarar quem eram seus respectivos senhores. Finalmente, os subscritores do aviso, o marquês de Pombal e o burguês enobrecido Joaquim Inácio da Cruz Sobral, Senhor do Morgado de Sobral de Monte Agraço, defendiam que "seria contrário à razão, e ao bem comum da Navegação" impedir "o aumento da gente da mareação de seus Navios", uma vez que "se podem habilitar muitos marinheiros pretos", a despeito de serem escravos. ${ }^{12}$ Desse modo, e de maneira paradoxal, a escravidão revelava-se uma instituição incontornável, imprescindível, à luz da razão e, principalmente, do princípio da prosperidade da navegação - este, aliás, um aspecto central das ideias fisiocráticas defendidas em todos os impérios coloniais da era moderna pela nobreza togada. ${ }^{13}$

O quinto texto legal é o aviso de 7 de janeiro de 1788, o qual reitera a imensa distância entre o centro e as periferias do império. Reforçando e alargando o texto legal precedente, o aviso de 1788 ratifica a permissão, consentida a senhores "do Brasil ou de outras Colônias Portugueses", para que pudessem ir ao reino levando seus marinheiros escravos "por falta de Marinheiros Brancos, e livres". No entanto, o mesmo texto proíbe "aos Vassalos habitantes de Portugal ou proprietários de Navios deste Reino", o emprego de marinheiros escravos, uma vez que "seria de perniciosas consequências se a Escravatura viesse privar os Marinheiros Brancos do último serviço da Marinha". Ademais, a intenção do aviso assinado pelo secretário de estado da marinha e ultramar, Martinho de Melo e Castro, e por José Joaquim Lobo da Silveira, então provedor da Casa da Índia e Guiné, era dupla: por um lado, lembrar que "a exceção do Aviso de 22 de Fevereiro de 1776 compreende tão somente os Escravos Marinheiros de profissão, e não os denominados tais" - isto é, aqueles cujos senhores apenas os faziam passar por marinheiros objetivando driblar o alvará de 1761. Por outro lado, a intenção do aviso de 1788 era impedir que, contra a lei, "o proprietário de qualquer Navio" retivesse seus escravos a bordo, bem como os vendessem "para onde os

12 Aviso, 22/02/1776, in Silva, Supplemento... v. 2, pp. 425-426.

13 Elias, O processo civilizador, pp. 56-64. 
tiver ajustado, debaixo do pretexto de pertencerem a equipagem do seu Navio, como já tem acontecido nesse Reino". ${ }^{14}$

O sexto e último texto legal, datado de 10 de março de 1800 , se refere, por sua vez, à mesma matéria do aviso de 1776, atinente aos marinheiros escravos. Embora apenas reitere os termos do aviso precedente, esse "alvará de declaração e ampliação" constitui, contudo, clara evidência de que as demandas de liberdade da marinhagem escrava haviam fugido ao controle dos indivíduos do nível mais alto. Ao mesmo tempo, o texto legal de 10 de março de 1800 revela uma atitude desesperada de Dom João, então príncipe regente, de manter o escravismo como um dos pilares da navegação. Assim, o "alvará de declaração e ampliação", por um lado, lamentava os "embaraços" à navegação e, por outro lado, apelava à "razão", em nome do "bem comum dos Meus Fiéis Vassalos", que não podiam ser obstados no "aumento da Gente de mareação de seus Navios, quando dos referidos Escravos se podem tirar Marinheiros hábeis, e peritos". Finalmente, esse "alvará de declaração e ampliação" condenava os senhores burladores e congregava um número bem maior de instituições da monarquia para que suas determinações fossem finalmente cumpridas. ${ }^{15}$

Os objetivos centrais desse corpo de leis nem eram "humanitários", como pensou quimericamente uma historiografia muito antiga, nem tampouco eram estritamente "econômicos", como sugeriram algumas análises mais recentes. ${ }^{16}$ Ao mesmo tempo, é também evidente que a legislação aqui examinada, como já sublinhamos em outra circunstância, bem como foi destacado em artigo recente sobre o mesmo tema, reiterava um enorme distanciamento entre a sociedade escravista da América e a sociedade com escravos da Europa. ${ }^{17}$ Sua preocupação central referia-se,

14 Alvará, 07/01/1788, in Silva, Supplemento... v. 2, pp. 600-601.

15 Aviso, 10/03/1800, in Silva, Collecção da Legislação Portugueza: v. 4: de 1791 a 1801 (Lisboa: Tipografia Maigrense, 1828), pp. 610-611.

16 Respectivamente, João de Saldanha Oliveira e Souza (Marquês de Rio Maior), "O Marquês de Pombal e a repressão da escravatura: a obra e o homem", VIII Congresso do Mundo Português, (Lisboa, 1940), pp. 106-111; Stuart B. Schwartz, Segredos internos: Engenhos e escravos na sociedade colonial, 1550-1835, São Paulo: Companhia das Letras, 1988, p. 384.

17 Silva, "Esperança de liberdade", pp. 107-149; Silva e Grinberg, "Soil Free from Slaves", pp. 431-446; Moses I. Finley, "Slavery", in David L. Sills (ed.), International Encyclopaedia of the Social Science: v. 14 (Nova York: Macmillan, 1968), pp. 308-309; Ira Berlin, Gerações 
pois, às relações sociais vividas no centro do império português, isto é, em sua "metrópole", e não em suas "colônias". Através dos textos legais examinados, nota-se que o desenvolvimento social do escravismo na América constituía aspecto a ser ampliado e promovido, ao passo que se acenava para uma extinção gradual dessa instituição no centro da figuração social imperial. A fim de produzir o efeito necessário em suas lutas contra a nobreza de espada, a nobreza togada e enriquecida no comércio colonial requeria aproximar a sociedade portuguesa o mais possível dos padrões de conduta e de gestão dos monopólios estatais - mormente os da violência legítima e da tributação - existentes nas demais "cortes polidas" da Europa.

Não por acaso, no alvará de 1761 qualifica-se o tráfico e o desembarque de escravos nos portos portugueses como um "excesso, e devassidão" e como atitudes que iam "contra as Leis, e costumes de outras Cortes polidas". Ao invés de se dedicarem "a cultura das Terras, e das Minas" na América, os escravos "só vêm a este Continente ocupar os lugares dos moços de servir, que ficando sem cômodo, se entregam à ociosidade, e se precipitam nos vícios, que dela são naturais consequências". No alvará de janeiro de 1773, por sua vez, se justifica a exclusão da "Nota distintiva de Libertos" como uma consequência de a "União Cristã" e a "Sociedade Civil" a tornarem "intolerável no Meu Reino, como o tem sido em todos os outros da Europa". À época das reformas, esse ponto de vista era, aliás, amplamente partilhado entre a nobreza togada de distintos reinos europeus, incluindo, claro, o pequeno reino ibérico do ocidente. ${ }^{18} \mathrm{E}$, com efeito, em O espírito das leis (1747), Montesquieu defende a ideia de que se deve "limitar a servidão natural a certos países particulares da terra. Em todos os outros", continua, "parece-me que, por mais penosos que sejam os trabalhos que a sociedade exige, se pode fazer tudo com homens livres". Ademais, argumenta que embora a escravidão fosse "contra a natureza", era certo, por outro lado, que tal instituição, "em certos países", ainda estava "fundada numa razão natural”:

de cativeiro: uma história da escravidão nos Estados Unidos, Rio de Janeiro: Record, 2006, pp. 20-21.

18 Eliga H. Gould, "Zones of Law, Zones of Violence: The Legal Geography of the British Atlantic, c. 1772", The William and Mary Quarterly, v. 60, n. 3 (2003), pp. 471-510. 
"deve-se distinguir bem estes países daqueles onde as próprias razões naturais a rejeitam, como os países da Europa", nos quais a escravidão "foi tão felizmente abolida". ${ }^{19}$

\section{Escravidão marítima: do mundo antigo ao moderno}

O modelo de análise baseado na presunção de que "os homens do mar foram um dos maiores e mais importantes grupos de trabalhadores livres remunerados na economia de mercado internacional do século XVIII", formulado na década de 1980 por Marcus Rediker, tem sido posto em questão nos últimos anos. ${ }^{20}$ Em contraponto a tal modelo tem-se desenvolvido o conceito de escravidão marítima, o qual, como formula Philip Morgan, se refere ao fato de que, ao longo do período moderno, fosse no mar, a bordo dos navios, fossem em terra, no âmbito das sociedades marítimas $^{21}$ contíguas aos portos, escravos desempenharam funções como as de pilotos, marinheiros, canoeiros, mergulhadores, tradutores, camareiros, cozinheiros e grumetes. Por outro lado, tal conceito também acena para a ideia de que, no âmbito dos estudos sobre escravidão, faz-se necessário prestar mais "atenção às comunidades marítimas" e aos "oceanos como arenas de interação, revertendo-se a ênfase costumeira conferida à terra em detrimento da água". ${ }^{22}$ Estudos dedicados aos impérios espanhol, britânico, português e holandês, têm demonstrado que, entre os séculos XVII e XVIII, na navegação interna ao Caribe, nas naus das companhias de comércio, a exemplo da poderosa Companhia Holandesa das Índias Ocidentais, e no tráfico de mercadorias entre a Europa,

19 Charles de Secondat (Baron de Montesquieu), O espirito das leis, São Paulo: Martins Fontes, 2000, pp. 258-259.

20 Marcus Rediker, Between the Devil and the Deep Blue Sea: Merchant Seamen, Pirates, and the Anglo-American Maritime World, Cambridge: Cambridge University Press, 1987, p. 77.

21 Entendemos por sociedades maritimas figurações sociais formadas por seres humanos cujo equilíbrio de poder depende de diferenciais baseados no saber sobre a natureza pré-humana marítima - isto é, as características específicas das espécies de animais pré-humanos e do meio físico, o que inclui o movimento das marés e a direção dos ventos e das correntes -, bem como sobre os instrumentos de navegação e de apropriação dos recursos móveis e não-renováveis existentes no mar.

22 Phillip Morgan, "Maritime slavery", Slavery and Abolition, v. 31, n. 3 (2010), pp. 311-326. 
América, África e Ásia, os escravos marinheiros poderiam perfazer até dois terços das tripulações dos navios. ${ }^{23}$

Em todos os impérios coloniais da era moderna parecia haver três modalidades predominantes de relações de trabalho envolvendo escravos marinheiros: a primeira era aquela em que senhores privados, vinculados ou não a uma sociedade marítima, alugavam seus escravos a marinheiros livres, capitães ou armadores de navios, os quais os inscreviam nos róis das embarcações. A segunda modalidade era aquela baseada na posse de escravos marinheiros por indivíduos que trabalhavam embarcados, fossem como capitães, capelães, cozinheiros, cirurgiões ou como marujos. A terceira modalidade era aquela na qual grandes armadores e comerciantes eram proprietários ou locadores de marinheiros escravos. Embora tivessem papel destacado na navegação de cabotagem no Caribe ${ }^{24}$ e na costa do Brasil, ${ }^{25}$ tais modalidades referem-se, sobretudo, à íntima conexão entre esse tipo particular de emprego de cativos e a navegação mercante e de longo curso - que incluía tanto a troca de mercadorias europeias, asiáticas e americanas, como a aquisição e transporte de escravos africanos. Conforme cada uma dessas modalidades, a soldada do marinheiro escravo poderia ser parcial ou totalmente embolsada por seus senhores. ${ }^{26}$

Em suma, o modelo de análise formulado por Rediker na década de 1980 encontra seu limite nas evidências empíricas atinentes à dependência que a navegação de longo curso levada a efeito nos impérios espanhol, português, holandês e britânico revela relativamente ao emprego

23 Respectivamente, José Manuel Vázquez-Lijó, "La matrícula de mar y sus repercusiones en la Galicia del siglo XVIII" (Tese de Doutorado, Universidad de Santiago de Compostela, 2005), pp. 65, 79-80, 443-444; Michael J. Jarvis, "Maritime Masters and Seafaring Slaves in Bermuda, 1680-1783", The William and Mary Quarterly, v. 59, n. 3 (2002), pp. 585-622; A. C. de C. M Saunders, História social dos escravos e libertos negros em Portugal (1441-1555), Lisboa: Imprensa Nacional-Casa da Moeda, 1994, pp. 32, 208-209; Matthias van Rossum, "Changing Tides Maritime Labour Relations in Europe and Asia", in: Karin Hofmeester e Pim de Zwart (eds.), Colonialism, Institutional Change and Shifts in Global Labour (Amsterdam: Amsterdam University Press, 2018), pp. 239-264.

24 Jarvis, "Maritime Master", pp. 585-622.

25 Silva, A faina, a festa e o rito, pp. 150-198; Luiz Geraldo Silva, "La captivité des eaux. Marins esclaves et violence à bord des navires de cabotage (Brésil, XIXe siècle)", in Mickaël Augeron e Mathias Tranchant, (eds.), La violence et la mer dans l'espace atlantique (XIIe-XIXe siècle) (Rennes : Presses Universitaires de Rennes, 2004), pp. 235-250.

26 A. C. de C. M. Saunders, História social dos escravos, p. 32; Jarvis, "Maritime Masters", p. 599; Vázquez-Lijó, La matricula de mar, pp. 79-80. 
de escravos marinheiros. Essas evidências acenam, ao mesmo tempo, para problemas analíticos importantes. O primeiro destes problemas se refere ao fato de que, no mundo moderno, no âmbito da escravidão que se desenvolveu em consonância com o capitalismo, a diversidade de tarefas desempenhadas pelos escravos africanos e afrodescendentes abarca um conjunto impressionante de setores e que, ao longo do tempo, tais tarefas tenderam a um refinamento impressionante, o que remete ao desenvolvimento de habilidades específicas apreendidas socialmente pelos escravos no artesanato urbano, no comércio e, como tentamos discutir aqui, na navegação e nas demais fainas marítimas. Em segundo lugar, o conceito de "escravidão marítima" formulado por Morgan constitui mais um aspecto que pode ser considerado à luz da teoria geral do escravismo - esta remete à ideia de que, por um lado, o escravismo constitui um campo de análise mais geral e, por outro lado, a escravidão americana, ou moderna, representa tão somente uma forma particular desta instituição de dimensão planetária e multissecular. ${ }^{27}$ Assim, a escravidão americana, moderna, é dotada de ramificações que a conectam com estruturas sociais e mentais do mundo antigo. Tais ramificações, portanto, persistem em muitas das ações, representações mentais e nos códigos legais presentes às sociedades do "mundo atlântico" e apenas são percebidas numa perspectiva de longo prazo.

Ora, sabe-se, por exemplo, que os escravos marinheiros “desempenharam um importante papel nos navios mercantes ao longo de toda a antiguidade"28 e que em Roma, particularmente nos últimos anos da república e nos primeiros séculos da fase imperial, mormente entre os séculos I a.C. e II, um grande número de escravos marinheiros foi deslocado das margens do Atlântico para o entorno do Mediterrâneo. As fontes sobre o emprego de escravos nos navios mediterrânicos de comércio, a exemplo do corpus demostênico, mostram essa atividade como algo recorrente desde o século IV a.C., ao passo que no século III, durante a expansão do império romano, a seção designada por digesto do código Justiniano refere-se às diversas funções exercidas pelos escravos nos navios mercantes, como as de oficiais, marinheiros e mestres de navios.

27 Kopytoff, "Slavery”, Annual Review of Anthropology, v. 11 (1982), pp. 207-230.

28 Beresford, The Ancient Sailing Season, Leiden: Brill, 2013, pp. 209-210. 
O emprego de escravos na navegação oceânica teria, ademais, transformado por completo a navegação comercial romana, ao mesmo tempo que "a tecnologia antiga de construção de navios e da expertise de navegação parecem ter alcançado seu apogeu" exatamente ao longo dessa etapa do mundo antigo. ${ }^{29}$ A perspectiva de longo prazo e o enfoque baseado na teoria geral do escravismo, nos permite propor, portanto, que não há exatamente uma novidade no emprego de marinheiros escravos no mundo moderno. No entanto, na modernidade capitalista de constituição do mercado mundial ${ }^{30}$ e de formação das economias-mundo dominadas sucessivamente por Veneza, Amsterdã e Londres, ${ }^{31}$ tal expediente tomou proporções bem mais vastas por comparação ao que se processou no mundo antigo. Ao contrário de sua internalização mediterrânica, verificada no império romano sobretudo entre os séculos I a.C. e o século II, o emprego de escravos marinheiros tomou proporções mundiais entre os séculos XVII e XIX, aspecto demonstrado pelas várias evidências de sua recorrência desde o Caribe, passando por toda a bacia do Atlântico, e chegando até o Índico. No entanto, tal expediente constituiu, no mundo moderno, uma recorrência estrutural da navegação de cabotagem e de longo curso cuja intensidade sofreu variações no âmbito de cada império colonial específico. Morgan sugere que a expansão da escravidão marítima teve sua "maior variação" quando se compara o Atlântico Norte e o Atlântico Sul: "Embora fossem encontrados através das bases do Atlântico Norte, o Atlântico Sul viu de longe mais marinheiros escravos que o Norte", uma vez que, por exemplo, "nos navios saídos do Brasil, os marinheiros escravos muitas vezes compreendiam ora a maioria, ora a metade, mas frequentemente um sexto das tripulações. Com efeito, os marinheiros escravos brasileiros representam o polo extremo no recrutamento de escravos marinheiros", ${ }^{32}$ por contraste às tripulações britânicas, espanholas, holandesas, francesas e mesmo portuguesas.

29 Beresford, The Ancient Sailing Season, pp. 209-210.

30 Immanuel M. Wallerstein, The Modern World-System: v. 1: Capitalist Agriculture and the Origins of the European Economy in the Sixteenth Century, Berkeley: University of California Press, 2011, pp. 300-346.

31 Fernand Braudel, Civilização material, economia e capitalismo: séculos XV-XVIII: v. 3: O tempo do mundo, São Paulo: Martins Fontes, 2006, pp. 11-74.

32 Morgan, "Maritime Slavery", p. 317. 


\section{Escravos marinheiros na América portuguesa}

Em artigos recentes, Mariana Cândido e Jaime Rodrigues discutiram o peso da escravidão marítima nos navios mercantes portugueses. O fundamento empírico de seus estudos foram sobretudo os "Registros de matrículas das equipagens", uma série vinculada ao fundo Junta do Comércio do Arquivo Nacional da Torre do Tombo que recobre os anos de 1767 a $1832 .{ }^{33}$ Uma vez que tais registros permitem a seriação de seus dados, eles puderam avaliar que nos navios registrados no porto de Lisboa ao longo daqueles anos o número de escravos marinheiros nos navios mercantes portugueses era ínfimo. Embora tenham clara consciência dos limites de suas fontes e as saibam explorar de forma criativa e pertinente, eles concluíram que o total de escravos empregados como marinheiros ao longo daqueles anos não ia além de 3\% num universo de 8.441 tripulantes, como destacou Cândido, ou de 3,8\% num conjunto de 5.279 indivíduos, como defende Rodrigues. ${ }^{34}$ Em duas outras amostragens considerando apenas os navios do tráfico entre o Rio de Janeiro e Angola, Herbert Klein constatou que para os anos de 1795 a 1811 os marinheiros escravos perfaziam $16,8 \%$ das equipagens, ao passo que Rodrigues apurou que 1812 e 1863 indivíduos desse grupo social constituíam cerca de $17 \%$ do total daquelas tripulações. ${ }^{35}$ No entanto, quando se dispõe de informações de pormenor sob a perspectiva das sociedades marítimas da América portuguesa e de avalições coevas para este mesmo período, pode-se sugerir contornos distintos relativamente ao volume do emprego de marinheiros escravos.

Através de um conjunto de cartas trocadas entre 1774 e 1775, isto é, ao longo da guerra luso-castelhana travada nas capitanias meridionais da América portuguesa, é possível demonstrar que a dependência da

33 Matrícula das equipagens dos navios, 27/04/1767, Arquivo Nacional da Torre do Tombo (ANTT), Junta do Comércio, livro 1; Mariana P. Cândido, "Different slave journeys: enslaved African seamen on board of Portuguese ships, c. 1760-1820s", Slavery \& Abolition, v. 31, n. 3 (2010), pp. 395-409; Jaime Rodrigues, "Circulação atlântica: idade, tempo de trabalho e funções de escravos e libertos na marinha mercante luso-brasileira, séculos XVIII e XIX", História, v. 34, n. 2 (2015), pp. 128-145; "Escravos, senhores e vida marítima no Atlântico", pp. 145-177.

34 Cândido, "Different Slave Journeys", p. 399; Rodrigues, "Circulação atlântica", p. 131.

35 Rodrigues, De costa a costa, p. 187; Herbert S. Klein, A escravidão africana: América Latina e Caribe, São Paulo: Brasiliense, 1987, pp. 91-92. 
navegação oceânica levada a efeito no âmbito do império português em relação ao escravismo era bem mais significativa que se possa concluir a partir dos "Registros de matrículas das equipagens". Naquela circunstância, o vice-rei do Estado do Brasil, marquês de Lavradio, enviou cartas aos governadores da Bahia, Manuel da Cunha Meneses, e de Pernambuco, José César de Meneses, solicitando informações sobre as populações marítimas de suas respectivas capitanias. O objetivo era recrutar marinheiros para a guerra então em curso na América meridional. ${ }^{36}$ Em março de 1775, antes mesmo de elaborar as listagens solicitadas por Lavradio, Manuel da Cunha Meneses advertiu o vice-rei de que na "frequente navegação da Costa de Mina e mais portos da África" em direção à Bahia, a qual contava com cerca de 20 navios por aquela época, "a maior parte das equipagens são escravos e quando muito levam 6 marujos brancos", ao passo que nas "embarcações miúdas da barra dentro só o mestre não é cativo". ${ }^{37}$

Os resultados apresentados em fins de 1775 pelos governos de ambas as capitanias reiteram essa percepção mais geral. Na Bahia, foram arrolados 1.873 marinheiros, dos quais 1.202 , ou $64,2 \%$, eram escravos. Ademais, os 671 marinheiros restantes são referidos no documento não como "livres", mas como "forros", o que significa que parte considerável dos que não eram escravos era composta por africanos ou afrodescendentes libertos ou livres e, portanto, indivíduos ainda atados ao seu próprio cativeiro pregresso ou ao de seus ascendentes. Por outro lado, se nota que Salvador, em particular, reunia a mais populosa sociedade marítima da capitania baiana: $61,3 \%$ dos marujos viviam na capital. No entanto, as maiores sociedades marítimas da capitania da Bahia se concentravam em apenas 2 de suas 32 freguesias: as de Nossa Senhora da Conceição da Praia e do Santíssimo Sacramento do Pilar, as quais conformavam, à

36 Ofício do vice-rei marquês de Lavradio para o governador Manuel da Cunha Menezes, no qual lhe requisita marinheiros para a esquadra do Rio de Janeiro, que tem sob as suas ordens, 24/12/1774, Arquivo Histórico Ultramarino (AHU), Bahia (BA), Col. Eduardo Castro Almeida (1613-1807), cx. 47, doc. 8745; Ofício do governador da capitania de Pernambuco, José César de Meneses, ao secretário de estado da Marinha e Ultramar, Martinho de Melo e Castro, remetendo mapa das embarcações, marinheiros e pescadores que existem na dita capitania e em suas anexas, segundo a ordem recebida, 10/10/1775, AHU, Pernambuco (PE), cx. 120, doc. 9196.

37 Ofício do governador Manuel da Cunha Meneses para Martinho de Mello e Castro, no qual informa largamente sobre o recrutamento dos marinheiros para as naus de guerra, 03/03/1775, AHU-BA, Col. Eduardo de Castro e Almeida, cx. 47, docs. 8745-8752. 
época, um continuum de terra à beira mar. Em Conceição da Praia residiam 499 marinheiros, dos quais 225 , ou $45 \%$ do total, eram escravos. $\mathrm{Na}$ vizinha freguesia do Santíssimo Sacramento do Pilar residiam 348 marinheiros, dos quais 101, ou 29\% do total, eram escravos. Estas duas freguesias concentravam, portanto, $43,4 \%$ de todos os marinheiros que residiam em Salvador e 26\% dos marujos que habitavam na capitania. Delas partia, conforme um estudo recente, a maior parte das tripulações de longo curso que seguiam em direção à Portugal, à Costa da Mina e à Índia. ${ }^{38}$ Contudo, a maioria dos marinheiros escravos estava concentrada nos então chamados "subúrbios da cidade", isto é, as freguesias de Pirajá, Paripe, Cotegipe, Matuim, Encarnação, Itaparica, Torre e Ipitanga, bem como nas sociedades marítimas do Recôncavo e do norte da capitania. Dos 226 marinheiros que viviam nas freguesias suburbanas de Salvador, 188 , ou $83 \%$ do total, eram escravos. ${ }^{39}$

Por sua vez, as informações colhidas em 1775 em Pernambuco compreendiam igualmente as chamadas capitanias anexas, isto é, Paraíba, Rio Grande do Norte e Ceará. Nestas capitanias, foram arrolados 752 marinheiros, dos quais 423 , ou $56,2 \%$ eram escravos. No entanto, havia uma particularidade em Pernambuco e nas capitanias anexas: o Recife era a única vila daquele sistema administrativo na qual habitavam marinheiros escravos. Isto tinha a ver com o fato de ali existir o único porto com conexões atlânticas da região setentrional da América portuguesa, o que o tornava o principal exportador dos gêneros produzidos naquelas capitanias e o principal receptor de mercadorias europeias, asiáticas, africanas e, principalmente, de seres humanos escravizados. ${ }^{40}$ Ademais,

38 Cândido Eugênio Domingues de Souza, 'Perseguidores da espécie humana': Capitães negreiros da Cidade da Bahia na primeira metade do século XVIII (Dissertação de Mestrado, Universidade Federal da Bahia, 2011), pp. 49-61.

39 Mapa geral de toda a qualidade de embarcações que há na Capitania da Bahia e navegação para a Costa da Mina, Angola, e outros portos da África, e todas as mais que navegam de porto a porto para o Rio de Janeiro, Pernambuco, Pará e outros portos da Costa do Brasil, como também dos barcos, lanchas e outras pequenas embarcações, que navegam pelos rios, ribeiras d'esta capitania, na condição dos víveres e pescado para a sua manutenção, com o número dos marinheiros e pescadores forros e cativos que há em toda a Capitania, freguesias em que residem, com aquela clareza e distinção possível, 27/05/1775, AHU-BA, Col. Eduardo de Castro Almeida (1613-1807), cx. 47, doc. 8789.

40 Thiago Dias, "Para além das capitanias: região colonial, espaço econômico e jurisdição política (séc. XVI-XVIII)”. Revista Territórios e Fronteiras, v. 11, n. 1, (2018), pp. 243-261. 
a condição de capitania geral conferida a Pernambuco a partir de 1656 tornava aquela vila - que, aliás, não era sua capital, mas sua estrutura urbana mais saliente e importante e seu único porto -, o principal centro comercial, administrativo, jurídico e militar da região setentrional da América portuguesa. ${ }^{41}$

Assim, portanto, 609 indivíduos, ou 81\% de todos os marinheiros que viviam em Pernambuco e nas capitanias anexas, residiam nas freguesias vizinhas ao porto do Recife - as de São Frei Pedro Gonçalves, Santo Antônio e Boa Vista - e, entre estes, os escravos perfaziam a larga maioria: eram 423 pessoas, ou quase $70 \%$ do conjunto dos marinheiros. ${ }^{42}$ Finalmente, parece importante ressaltar que em meados do século XVIII a maior parte dos navios surtos nos portos da Bahia e de Pernambuco destinavam-se às rotas que, partindo da América portuguesa, se dirigiam a Luanda, Benguela e à Costa da Mina. Eram estas rotas do tráfico as que mais empregavam marinheiros escravos. Em 1749 o governador e capitão general Luís Correia de Sá elaborou uma lista com todos os navios de longo curso - corvetas, bergantins, galeras e patachos -, cuja propriedade era de um ou mais comerciantes residentes na vila do Recife. Ao todo, essa lista aponta para 16 navios de longo curso pertencentes àqueles indivíduos, dos quais 11 , ou $69 \%$ das embarcações, destinavam-se exclusivamente ao tráfico de seres humanos. ${ }^{43}$ Por volta de 1758 , esse número havia aumentado para 19 navios

41 Mozart Vergetti de Menezes, "Jurisdição e poder nas capitanias do Norte (1654-1755)", Saeculum, n. 14 (2006), pp. 11-25; José Inaldo Chaves Júnior, “Por ser Pernambuco tão chegado': anexação, governos e mercados ultramarinos na Capitania da Paraíba (1791-1799)", Almanack, v. 8, n. 2 (2014), pp. 120-141; Denis A. de Mendonça Bernardes, "Pernambuco e sua área de influência: um território em transformação (1780-1824)", in István Jancsó (org.), Independência: história e historiografia (São Paulo: Hucitec, 2003), pp. 379-410.

42 Ofício do governador da capitania de Pernambuco, José César de Meneses, ao secretário de estado da Marinha e Ultramar, Martinho de Melo e Castro, remetendo mapa das embarcações, marinheiros e pescadores que existem na dita capitania e em suas anexas, segundo a ordem recebida, 10/10/1775, AHU-PE, cx. 120, doc. 9196.

43 15/02/1723, AHU-PE, cx. 30, doc. 2666; 12/07/1724, AHU-PE, cx. 30, doc. 2746; 26/03/1732, AHU-PE, cx. 42, doc. 3822; 10/08/1734, AHU-PE, cx. 47, doc. 4179; 23/06/1735, AHU-PE, cx. 48. doc. 4318; 13/09/1735, AHU-PE, cx. 49, doc. 4332; 23/09/1738, AHU-PE, cx. 52, doc. 4600; 15/04/1742, AHU-PE, cx. 57, doc. 4931; 30/07/1742, AHU-PE, cx. 58, doc. 4962; 04/02/1745, AHU-PE, cx. 61, doc. 5236; 14/06/1745, n. 41066, in Emory Center for Digital Scholarship, "Banco de Dados do Tráfico Transatlântico de Escravos" (BDTTE), <https:// www.slavevoyages.org>, acessado em 07/05/2020; 19/06/1745, AHU-PE, cx. 61, doc. 5269; 16/10/1745, AHU-PE, cx. 62, doc. 5294; 20/10/1745, AHU-PE, cx. 62, doc. 5305; 27/10/1745, 
surtos no porto do Recife. ${ }^{44}$ Por volta de 1775 , havia na capitania da Bahia, num universo de 44 navios, 20 embarcações destinadas ao tráfico de escravos, as quais, como sentencia o governador Cunha Meneses em maio daquele ano, "costumam equipar-se com uma pequena equipagem de 4 ou 6 Marinheiros brancos, suprindo os pretos cativos para o resto da mareação de que carecem". ${ }^{45}$ Por volta de 1758 , um navio surto no Recife que tomava a direitura de Angola tinha, em média, além de um capitão, um piloto e de um contramestre, cerca de 15 marinheiros. ${ }^{46}$ Isto talvez signifique que a maior parte das tripulações das embarcações do tráfico que partiam do Recife ou de Salvador e seguiam até Luanda na segunda metade do século XVIII, como bem destacou Morgan, fosse composta sobretudo por marinheiros escravos que partiam até a África

\begin{abstract}
AHU-PE, cx. 62, doc. 5312; 05/01/1747, AHU-PE, cx. 65, doc. 5502; 05/01/1747, AHU-PE, cx. 65 , doc. $5502 ; 28 / 01 / 1747$, n. 8777 , in Emory Center for Digital Scolarship, "BDTTE"; 25/02/1747, AHU-PE, cx. 65, doc. 5514; 27/02/1747, AHU-PE, cx. 65, doc. 6516; 12/08/1747, n. 8832, in Emory Center for Digital Scholarship; 28/03/1748, AHU-PE, cx. 67, doc. 5688; 28/05/1748, n. 8820, in BDTTE; 26/05/1749, n. 46696, in BDTTE; 21/06/1749, n. 8846, in BDTTE; 26/09/1749, AHU-PE, cx. 69, doc. 5871; "Informação geral da capitania de Pernambuco, 1749", Anais da Biblioteca Nacional, v. 28, 1906, p. 431; 09/11/1750, AHU-PE, cx. 71, doc. 5984; 20/02/1751, AHU-PE, cx. 71, doc. 6001; 04/08/1752, n. 47666, in BDTTE; 20/03/1754, AHU-PE, cx. 75, doc. 6321; 19/08/1750, AHU-PE, cx. 70, doc. 5949; Autos de Petição de José Vaz Salgado, 02/09/1756, ANTT, Feitos Findos, Juízo da Índia e Mina, Justificações Ultramarinas, Brasil, maço 308, n. 7; 30/03/1758, n. 8871, in BDTTE; 14/01/1761, AHU-PE, cx. 94, doc. 7456; 12/05/1755, AHU-PE, cx. 79, doc. 6553; 18/04/1757 n. 41119, in BDTTE; 22/10/1757, AHU-PE, cx. 85, doc. 7019; Agravo crime em que é agravante Manuel de Oliveira Garrido e agravado António José Brandão, 03/08/1765, ANTT, Feitos Findos, Conservatória da Companhia Geral de Pernambuco e Paraíba, cx. 2, n. 2, maço 2; 25/04/1777, AHU-PE, cx. 126, doc. 9588; 12/12/1785, AHU-PE, cx. 155, doc. 11218.
\end{abstract}

44 Ofício do governador Luís Diogo Lobo da Silva ao secretário de estado da marinha e ultramar, Tomé Joaquim da Corte Real, remetendo a relação dos navios empregados no transporte de escravos da Costa da Mina e Angola para Pernambuco, 12/11/1758, AHU-PE, cx. 87, doc. 7129.

45 Mapa geral de toda a qualidade de embarcações que há na Capitania da Bahia e navegação para a Costa da Mina, Angola, e outros portos da África, e todas as mais que navegam de porto a porto para o Rio de Janeiro, Pernambuco, Pará e outros portos da Costa do Brasil, como também dos barcos, lanchas e outras pequenas embarcações, que navegam pelos rios, ribeiras d'esta capitania, na condição dos víveres e pescado para a sua manutenção, com o número dos marinheiros e pescadores forros e cativos que há em toda a Capitania, freguesias em que residem, com aquela clareza e distinção possível, 27/05/1775, AHU-BA, Col. Eduardo de Castro Almeida (1613-1807), cx. 47, doc. 8789.

46 Ofício do governador Luís Diogo Lobo da Silva ao secretário de estado da marinha e ultramar, Tomé Joaquim da Corte Real, remetendo a relação dos navios empregados no transporte de escravos da Costa da Mina e Angola para Pernambuco, 12/11/1758, AHU-PE, cx. 87, doc. 7129; Jaime Rodrigues, De costa a costa, pp. 167-169. 
para obter outros escravos destinados aos mais diversos ofícios - dentre eles, a navegação atlântica.

\section{Liberdade, escravidão e campo pendular de tensões}

Uma vez sabedores dos alvarás de 1761 e de 1773, bem como dos avisos de 1767, 1776, 1788 e 1800, senhores e locatários da Bahia, de Pernambuco, do Rio de Janeiro e de Lisboa procuraram ao máximo salvaguardar suas prerrogativas de usufruidores de seres humanos que desempenhavam funções altamente especializadas e vitais para seus negócios e para o império. Por outro lado, os próprios marinheiros escravos, fossem propriedade ou objeto de locação de senhores do Brasil, de Angola ou de Portugal, tenderam a representar mentalmente que podiam alcançar o status de liberto graças ao campo pendular de tensões involuntariamente criado por indivíduos do nível mais alto através da publicação das leis aqui em questão. As cadeias de interdependências que ligavam as subfigurações americanas e europeia mediante a navegação oceânica, bem como o próprio advento das leis, haviam criado aquele campo pendular de tensões cuja lógica relativamente autônoma e mutável poderia, malgrado sua posição social de escravos, lhes favorecer em seus pleitos pela liberdade. Por sua vez, oficiais das várias repartições da alfândega existentes nos portos do império, sobretudo no de Lisboa, bem como oficiais da junta de comércio, conselheiros ultramarinos, secretários de Estado e os próprios monarcas tiveram que mediar as demandas senhoriais e os pleitos dos cativos. Esses indivíduos e grupos sociais do nível mais alto, como funcionários ou mandatários de instituições da monarquia, não poderiam se furtar ao seu papel mediador nesse campo pendular de tensões, uma vez que, se assim o fizessem, a estrutura jurídica que eles haviam construído poderia ruir. O entrelaçamento das ações e representações mentais de todos esses indivíduos e grupos sociais, situados em diferentes posições e níveis sociais, e não apenas a "agência" unilateral, unipolar e estática dos escravos, constituiu a matéria por excelência desse campo pendular de tensões, cuja existência ninguém planejou ou previu. ${ }^{47}$ Explicar os resultados de processos desencadeados por petições

47 Em suas análises, Rodrigues, “Escravos, senhores e vida marítima no Atlântico”, pp. 145-177, 
elaboradas não apenas por escravos, mas também por seus senhores e locatários, bem como analisar as avaliações dessas petições por indivíduos ligados à justiça e à administração monárquicas, pressupõe o exame desses entrelaçamentos de ações e representações mentais e de sua dinâmica cega, mas dotada de estrutura e coerência.

Para efeito dessa análise examinamos algumas demandas de escravos por cartas de liberdade, bem como petições e processos movidos por seus senhores e locadores. Uma primeira conclusão mais geral que se impõe à análise refere-se ao fato de que os pareceres conclusivos de processos baseados nos alvarás e avisos antes examinados tenderam a beneficiar tanto a senhores como a escravos. Ao mesmo tempo, nesses pareceres alguns tópicos aparecem de forma recorrente, constituindo diretrizes mais gerais. Bem ou mal, tais diretrizes haviam sido definidas naquele corpus legal em consonância com a ordem da sociedade de tipo antigo em sua etapa reformista e com a tradição escravista do Ocidente - a qual tem início no mundo antigo clássico com a criação, por um lado, do "escravo-mercadoria" e, por outro lado, do conceito de "liberdade". ${ }^{48}$ É possível enumerar, ao menos, quatro desses princípios mais gerais. O primeiro deles, aliás bastante óbvio, era a defesa da própria escravidão. Por aqueles anos, no âmbito do império português, em nenhum momento se pensou que esta instituição poderia ser abolida em Portugal, muito menos nas "colônias". Apenas tentava-se mitigá-la e, no limite, prever sua abolição no "reino" em consonância com outras "cortes polidas" da Europa. Em segundo lugar, procurava-se salvaguardar o direito à alforria do escravo tanto em conformidade com o alto valor atribuído à liberdade nos avisos e alvarás, como quando se constatava a burla dos códigos legais por parte de senhores e locadores. Em terceiro lugar, os pleitos que favoreciam aos últimos eram exatamente aqueles em que os escravos tinham reconhecida experiência, habilidade e competência nas lides maritimas e, ao mesmo tempo, estavam devidamente registrados nas equipagens. Nesses casos, o argumento atinente à enorme dependência

pretende explicar o objeto em questão ressaltando sobretudo o que chama de "perspectivas de liberdade de marinheiros escravos"; por sua vez, Cândido, "Different Slave Journeys", p. 396, também procura explicar este objeto sobretudo mediante o que chama de "agência dos marinheiros".

Finley, "Entre a escravatura e a liberdade", pp. 89-109. 
do império e de sua navegação comercial relativamente aos escravos marinheiros era sempre esgrimido quando se justificava a negação de suas cartas de liberdade. Em quarto e último lugar, notamos que se dispensava tratamento diferenciado a senhores ou locadores do reino e das “colônias". Distintamente do que se processava com aqueles indivíduos cujas praças comerciais se situavam nas periferias do império, os senhores e locadores do reino eram, em geral, grandes armadores e comerciantes de grosso trato enobrecidos, vinculados tanto à governação "ilustrada" como às redes de grande penetração em circuitos comerciais da "economia-mundo". Ademais, estes indivíduos transitavam com desenvoltura entre os oficiais responsáveis pelas instâncias que emitiam ou indeferiam as cartas de liberdade. Tais instâncias, aliás, se iniciavam na ouvidoria da alfândega de Lisboa e na junta de comércio, passavam pela Juízo da Índia e Mina e, raras vezes, se concluíam na Casa de Suplicação.

\section{Marinheiros escravos, senhores e locadores: campo de tensões}

Em dezembro de 1780 cinco escravos de um mesmo senhor, Teodósio Gonçalves da Silva - um importante traficante português radicado na Bahia desde inícios do século XVIII ${ }^{49}$-, partiram em direção a Lisboa a bordo do navio Santíssimo Sacramento e Nossa Senhora da Arrábida. ${ }^{\mathbf{5 0}}$ $\mathrm{Na}$ capital do império, solicitaram suas cartas de liberdade em virtude do alvará de $1761 .^{51}$ Coube, então, aos deputados da junta de comércio, elaborar o "parecer a respeito de ficarem os ditos pretos conservados na escravidão, ou reputados livres". Apurou-se, em primeiro lugar, que quatro daqueles escravos eram empregados em "serviços domésticos": o parecer refere-se a uma escrava não nominada que servia "de dentro de sua casa", a dois outros escravos, Amaro e Sebastião, ambos africanos,

49 Alexandre Vieira Ribeiro, "O comércio das almas e a obtenção de prestígio social: traficantes de escravos na Bahia ao longo do século XVIII”, Locus, v. 12, n. 2 (2006), pp. 9-27.

50 Este processo também foi examinado por Rodrigues, "Escravos, senhores e vida marítima no Atlântico", pp. 158-160.

51 Consulta da Junta do Comércio do Reino à Rainha, D. Maria I, sobre a pretensão dos pretos vindos da Bahia a bordo do navio Santíssimo Sacramento e Nossa Senhora da Arrábida, como de Teodósio Gonçalves da Silva, os quais intentam reivindicar sua liberdade em virtude do alvará de 19 de setembro de 1761, 19/12/1780, AHU-BA, cx. 180, doc. 70. 
que se ocupavam em conduzir seu senhor "na cadeirinha", e a um terceiro escravo, Antônio, que desempenhava a função "de acompanhá-lo como lacaio", ao mesmo tempo que sabia "alguma coisa do Ofício de alfaiate". ${ }^{2}$ Em segundo lugar, apurou-se que o último escravo demandante, chamado Pedro, "antes de vir para esta corte fizera uma viagem da dita cidade da Bahia à Costa da Mina" exercendo a função de marinheiro. ${ }^{53}$ Astutamente, Teodósio Gonçalves da Silva matriculou todos os escravos do sexo masculino como membros da equipagem de seu próprio navio - apenas uma, aliás, de suas seis embarcações.

Uma vez que o conjunto dos oito deputados da junta de comércio levaram em consideração tanto "o benefício da liberdade dos Escravos" como o desenvolvimento da navegação, sua decisão não foi unânime. Por um lado, cinco oficiais tenderam para "a causa da liberdade", em "favor da qual pugnam a natureza, a humanidade, as leis e costumes das nações civilizadas", e foram favoráveis a que "os ditos três pretos por nomes Amaro, Sebastião, e Antônio", bem como "a preta que trouxe o dito Capitão e que ainda conserva na sua companhia", deveriam ser alforriados. Contudo, dever-se-ia "pelo contrário, conservar-se o escravo Pedro no estado da sua condição", uma vez que "se achava destinado e empregado no serviço marítimo". ${ }^{54}$ Três outros oficiais, entretanto, votaram diversamente dos primeiros. Eles concluíram, "que os escravos de que se trata, excetuando a preta, devem todos conservar-se na mesma condição". O voto contrário se baseou no aviso de 1776: para eles, a prosperidade do império português e de sua navegação estaria ameaçada caso não se observasse o princípio do "aumento da gente necessária para a mareação dos navios daquele continente" e se fossem libertados todos os que "viessem matriculados na equipagem com as necessárias informações". Assim, portanto, prevaleceu entre os três oficiais a tese conforme a qual a interpretação do alvará de 1761 não deveria pender "tanto a favor da liberdade de que se querem valer" os escravos, mas, antes, "à razão Política, e econômica que no mesmo se menciona". Os fundamentos

52 Carta de Teodósio Gonçalves da Silva negociante da praça da Bahia, ao governador-geral a referida capitania, Afonso Miguel de Portugal e Castro, marquês de Valença, referente à concessão de liberdade a alguns de seus escravos, 28/08/1781, AHU-BA, cx. 183, doc. 57.

53 Consulta da Junta do Comércio do Reino à Rainha, D. Maria I, 19/12/1780, op. cit.

54 Consulta da Junta do Comércio do Reino à Rainha, D. Maria I, 19/12/1780, op. cit. 
teóricos de ambos os votos eram, portanto, radicalmente opostos entre si, e acenavam para interpretações distintas do alvará de 1761 e do aviso de 1776. Ao fim e ao cabo, os deputados remeteram a decisão à Dona Maria I, a quem cabia deliberar "o que for mais do seu Real Agrado". 55

Coerentemente, a monarca optou pela "causa da liberdade". Em 28 de agosto de 1781 os africanos Amaro e Sebastião, receberam suas cartas de alforria. Uma vez que ambas foram registradas em Lisboa, sabe-se que suas demandas foram resolvidas ainda na capital do império e cerca de seis meses depois de elaborado o inconcluso parecer da junta de comércio. ${ }^{56}$ Não encontramos evidências para o caso da "preta" cujo nome jamais aparece nos autos, mas esta foi, no âmbito da junta, a única pessoa cujo direito à manumissão foi reconhecido unanimemente. Também não obtivemos informações precisas acerca do paradeiro de Antônio, que fazia às vezes de lacaio de seu senhor. Mas parece provável que seu destino não diferiu dos demais. Não por acaso, a exceção era Pedro, o único que detinha experiência, habilidades e competência marítimas - razão pela qual foi mantido em cativeiro. À época em que a junta de comércio proferiu seu controverso parecer, ele já havia sido embarcado como marinheiro escravo.

Em agosto de 1779, por sua vez, foi recebida em Lisboa petição que informa que cinco escravos marinheiros - Vicente Ferreira, Ambrósio Roque, Manoel Pereira, Ventura Soares e Caetano José, todos africanos -, pertencentes a Manoel Gomes Cardoso, "comerciante da praça do Rio de Janeiro", e a seu sócio, José Carneiro da Sylva, "morador em Benguela", bem como a José Luís Vianna, capitão da Corveta Nossa Senhora do Rosário Santo Antônio e Almas, tinham, "por conselhos, e sugestões de alguns pretos libertos" de Lisboa, elaborado sucessivas petições sob o desiderato de "subtraírem-se do poder e autoridade de seus respectivos senhores". Uma vez que nada havia de errado com suas matrículas naquela embarcação, os escravos marinheiros alegaram em suas petições que sofriam "sevícias de escravidão" - uma estratégia legítima, embora supostamente caluniosa. Em seu requerimento à

55 Consulta da Junta do Comércio do Reino à Rainha, D. Maria I, 19/12/1780, op. cit.

56 Carta de Teodósio Gonçalves da Silva negociante da praça da Bahia, ao governador-geral, 28/08/1781, op. cit. 
rainha, Manoel Gomes Cardoso diz compreender o ponto de vista dos escravos: afinal, sua "servil condição" lhes levava facilmente ao "dolo, à calúnia”, e a "quantas imposturas julgarem necessárias para se subtraírem do julgo da escravidão". Por outro lado, argumentava que aqueles indivíduos eram absolutamente imprescindíveis, não apenas "no uso da navegação", mas também no "comércio de Benguela, e de toda a Costa de África por lhes servirem de língua aos pretos boçais que se costumam extrair daqueles países". Atuando não apenas como marinheiros, mas também como intérpretes e tradutores, os escravos aqui em questão constituíam verdadeiros esteios do tráfico, pois cumpriam funções primordiais na aquisição de cativos. ${ }^{57}$

O próprio provedor da alfândega de Lisboa, Joaquim Ignácio da Cruz Sobral, escreveu parecer no qual concluiu "que não há as sevícias, que se alegam". Antes, "pelas informações particulares que tirei”, aqueles indivíduos "eram contentes de seu cativeiro, e tratados, como o são todos os mais negros marinheiros, que andam em semelhantes viagens". ${ }^{58}$ Uma pergunta final em torno desse caso se impõe: escravos podem estar "contentes em seu cativeiro"? Em seu ensaio sobre o direito em pessoas e parentesco na África, Suzanne Miers e Igor Kopytoff formularam a ideia de que, na literatura sobre a escravidão, "os escravos têm que parecer infelizes. Se não o são, ou sua autonomia não é tão limitada ou eles simplesmente não sentem que são". ${ }^{59}$ Para esses antropólogos, a infelicidade incondicional dos escravos constitui um dos vários estereótipos que caracterizam as representações da escravidão do Ocidente - bem como que atestam seu sentimento de culpa. Neste caso, podemos até duvidar das testemunhas, mas, talvez, devêssemos, antes, indagar o que significa estar "contente" no cativeiro. Esses indivíduos não estavam

57 Requerimento do comerciante da praça do Rio de Janeiro, Manoel Gomes Cardoso, à rainha D. Maria I, solicitando para que o provedor da Alfândega do Rio de Janeiro averigue junto dos negociantes de Lisboa a conduta do suplicante e do tratamento aplicado a 5 escravos seus, de modo a apelar da acusação de maus tratos contra si proferida pelos ditos escravos, uma vez que os mesmos apenas pretendiam alcançar a sua liberdade e regressar a Benguela, sua pátria, 07/08/1779, AHU, Rio de Janeiro (RJ), cx. 110 doc. 9172.

58 Requerimento do comerciante da praça do Rio de Janeiro, Manoel Gomes Cardoso, à rainha D. Maria I, 07/08/1779, op. cit.

59 Suzanne Miers e Igor Kopytoff, “African 'Slavery' as an Institution of Marginality”, in Suzanne Miers e Igor Kopytoff (eds.), Slavery in Africa: Historical and Anthropological Perspectives (Madison: The University of Wisconsin Press, 1979), pp. 3-4. 
presos à terra. Movimentam-se regularmente entre portos africanos e brasileiros e eram imprescindíveis a seus senhores não apenas por suas habilidades e competências náuticas, mas também porque eram intérpretes, o que os faziam participar diretamente dos negócios na costa da África. Consequentemente, sua autonomia e a enorme dependência de seus senhores relativamente a eles acena para uma posição de status na escravidão distinta de muitos outros escravos, mormente daqueles vinculados à plantation escravista. No mínimo, deve-se concluir que é preciso repelir os estereótipos e encarar a diversidade da escravidão e os vários graus de autonomia e "liberdade" que ela compreendia. ${ }^{60}$ É nesses termos que, sim, claro, Vicente Ferreira, Ambrósio Roque, Manoel Pereira, Ventura Soares e Caetano José poderiam perfeitamente "estar contentes em seu cativeiro".

Em fins da década de 1780, por seu turno, um escravo, Hilário de Freitas Antunes, e seu senhor, Feliciano dos Santos, enviaram distintas petições em torno de um mesmo assunto: enquanto o escravo demandava sua liberdade em decorrência do alvará de 1761, seu senhor arremetia na direção contrária. Como era recorrente nessa estrutura social, Feliciano dos Santos era um comerciante e traficante de escravos que, à sua posição social, agregou títulos nobiliárquicos e funções sociais de prestígio que o distinguiam na sociedade de tipo antigo. Hilário, por sua vez, era um escravo crioulo, nascido em Pernambuco - um indivíduo que, na escravidão, tinha uma posição de status distinta de um africano, e que, bem mais que este, dominava os códigos da sociedade na qual vivia. Como se escreve em sua "carta de liberdade", o escravo Hilário de Freitas Antunes era marinheiro "em o Navio Nossa Senhora da Penha de França", o qual entrou no porto de Lisboa em 1786. O navio em questão, contudo, ficou estacionado naquela cidade até 1788, razão pela qual Hilário teve sua petição acolhida, recebendo, pois, sua "carta de liberdade" a $1^{\circ}$ de novembro de $1788 .{ }^{61}$ Desse modo, Hilário retornou "aos

60 Jeffrey Bolster, “'To Feel Like a Man’: Black Seamen in the Northern States, 1800-1860”, The Journal of American History, v. 76, n. 4 (1990), pp. 1173-1199; Arthur L. Stinchcombe, "Freedom and Oppression in the Eighteenth-Century Caribbean", American Sociological Review, v. 59, n. 6 (1994), pp. 911-929.

61 Requerimento de Hilário de Freitas Antunes ao governador do Maranhão e Piauí, Fernando Pereira Leite de Foios, pedindo licença para ir à Corte tratar de matéria relativa à sua liberda- 
estados da América pela escala de Pernambuco, sua pátria", dirigindo-se, posteriormente "à cidade do Maranhão". Em seu destino final, contudo, teve o enorme desprazer de ser "preso e recolhido no Corpo da Guarda da praça" graças a uma demanda de seu antigo senhor, que argumentou junto ao governo da capitania que "lhe mandasse entregar o suplicante por ser seu escravo fugitivo". Depois de sua estada na cadeia pública, Hilário foi entregue a seu ex-senhor, que o trancafiou "em aspérrima prisão de ferros em sua própria casa", ademais "carregando-o de ferros, e fazendo-lhe ímpios e tiranos tratos". ${ }^{62}$ Tal situação perdurou até 1792, quando Hilário conseguiu, mais uma vez, peticionar por sua liberdade junto à monarca. ${ }^{63}$ Tal situação apenas foi revertida quando "o procurador geral dos índios", que militava igualmente na "Junta das liberdades daquele Estado", foi levado "pelos deveres de seu ofício, e compaixão", a averiguar o estado de Hilário. Após abertura de devassa, Feliciano dos Santos acabou sendo preso; "porém, como poderoso e cheio de astúcias", obteve "na Junta da Justiça sentença de absolvição por um lavrado" em março daquele ano. ${ }^{64}$

A partir daí se inicia uma batalha entre o liberto e seu ex-senhor através de petições que se estende até 1801: ao passo que o primeiro insiste em que este último retorne a cadeia e o indenize pelos dias em que, sendo homem livre, esteve em cárcere privado, o segundo reitera que o seu antigo escravo tinha sido libertado ilegalmente, e que, portanto,

de, pois, sendo preto liberto, continuava mantido em cativeiro, 19/07/1792, AHU, Maranhão (MA), cx. 80, doc. 6799; Requerimento do capitão de mar e guerra da Armada Real, Feliciano dos Santos, ao príncipe regente D. João, solicitando castigo para seu escravo por este ter se matriculado como marinheiro, 16/10/1799, AHU-MA, cx. 106, doc. 8418.

62 Requerimento do capitão de mar e guerra da Armada Real, Feliciano dos Santos, ao príncipe regente D. João, 16/10/1799, op. cit.

63 Requerimento de Hilário de Freitas Antunes à rainha, Dona Maria I, pedindo reintegração da sua liberdade, que tinha sido usurpada pelo seu antigo dono, Feliciano dos Santos, 05/06/1792, AHU-MA, cx. 80, doc. 6777; Requerimento do oficial prático da costa e portos da América, Hilário de Freitas Antunes, homem preto natural de Pernambuco, ao príncipe regente D. João solicitando ordens para que se apure e paguem os vencimentos do posto que exerce, correspondentes aos anos em que o suplicante ficou retirado em cárcere privado no Maranhão porque seu antigo dono, Feliciano dos Santos, não respeito a carta de alforria que the foi concedida em 22 de novembro de 1788, assim que se julgue o dito senhor pelo crime cometido, 06/09/1802, AHU, Avulsos, cx. 34, doc. 2782.

64 Requerimento do capitão de mar e guerra da Armada Real, Feliciano dos Santos, ao príncipe regente D. João, 16/10/1799, op. cit. 
deveria retornar ao cativeiro. ${ }^{65}$ Contudo, quando Hilário solicitou formalmente que seu antigo senhor fosse encarcerado pelos crimes que cometeu contra sua liberdade, a escravidão falou mais alto. Um parecer do Conselho Ultramarino cujo autor não conseguimos identificar, diz concordar com seu pedido de ter provisão definitiva e firmada pela rainha sobre sua liberdade. No entanto, a solicitação de que seu antigo senhor fosse "tornado à prisão para se rever a culpa, não merece atenção". O argumento central baseou-se em um preceito romano conforme o qual "nem ao liberto se deve conceder o perseguir e ser parte a quem foi seu senhor, e por isto no que a sua presunção tem de odiosa, merece ser repelida". ${ }^{66}$ Como argumenta Moses Finley, em Roma um "liberto adquiria o estatuto do seu antigo senhor", e podia tornar-se "cidadão", mas sua incapacidade consistia precisamente na impossibilidade de se envolver em querelas contra ele. ${ }^{67}$

Um outro processo semelhante ao de Hilário teve curso em fins da década de 1790, e envolveu "o preto Caetano, de nação Angola", e seu senhor, Jacinto de Campos Brito, cirurgião do navio Flor do Mar. Numa de suas frequentes viagens entre o porto do Recife e a capital do império, Caetano tornou-se "forro pelas leis novíssimas"; no entanto, tão logo conquistou sua carta de liberdade, o escravo marinheiro agora em questão recebeu proposta sedutora de seu antigo senhor: "podia voltar a Pernambuco no dito navio, aonde ia ganhando a sua soldada". Contudo, desde que embarcou no navio, seu destino foi bastante diverso. Já a bordo do Flor do Mar, o cirurgião Jacinto de Campos Brito determinou "ao capitão para o despachar por escravo quando voltou para Pernambuco, o que assim o fez o dito por ser amigo e sócio do tal cirurgião". Ao longo da travessia atlântica, Caetano, como ele próprio narra, "passou a maior desgraça" e, chegando a Pernambuco, se viu ainda em

65 Consulta do Conselho Ultramarino ao príncipe regente D. João sobre o requerimento de Feliciano dos Santos, reativo à anulação da liberdade de seu escravo, Hilário de Freitas Antunes, 20/07/1801, AHU-MA, cx. 117, doc. 9031; Requerimento do oficial prático da costa e portos da América, Hilário de Freitas Antunes, homem preto natural de Pernambuco, ao príncipe regente D. João, 06/09/1802, op. cit.

66 Parecer do Conselho Ultramarino para a rainha D. Maria I, sobre as queixas de Hilário de Freitas Antunes a Feliciano dos Santos, requerendo que este seja punido e lhe pague perdas e danos, e que a sua carta de liberdade tenha validade, 20/07/1795, AHU-MA, cx. 87, doc. 7247.

67 Finley, "Entre a escravatura e a liberdade", pp. 96-100. 
piores circunstâncias. Tão logo desembarcou, seu antigo senhor solicitou a um escravo, "um preto por nome Lucas, do gentio da Costa", que o acompanhasse ao engenho Maragi, na freguesia de Una, para "buscar um pouco de dinheiro". ${ }^{68}$ Era uma armadilha.

Assim, pois, chegando "ao dito engenho Maragi", munido de "carta ao senhor do dito engenho, chamado capitão José Rodrigues Senna", este, tão logo leu a missiva, "fez atar ao suplicante em cima de um carro, e de corpo nu o mandou açoitar na forma da ordem do suplicado, perguntando se era forro ou cativo". Ao longo de seu suplício, Caetano foi açoitado "enquanto dizia que era forro em Lisboa, e só quando disse que era cativo" seu novo senhor "o mandou soltar". Ademais, o marinheiro agora liberto foi reescravizado e vendido a José de Rodrigues Senna por 80 mil réis. Dessa forma, ele perdeu o status decorrente de sua mobilidade social no cativeiro, e se tornou um escravo do eito, preso à plantation escravista. Em sua petição dirigida à Dona Maria I por volta de abril de 1799, Caetano ainda se dizia "gemendo no dito cativeiro às crueldades de escravo, sendo forro pelas sagradas leis de vossa majestade". Quando foi recebida em Lisboa, em abril de 1799, a petição em questão, escrita por seu procurador, João Garcia, causou indignação. O parecer exarado a partir daquela petição determinou que se informasse "aos governadores interinos, e sendo verdadeiros estes fatos, darão a providência que necessita esta crueldade, fazendo pôr ao suplicante no estado de liberdade que tinha, e proceder imediatamente ao castigo que merece o suplicado e mais cúmplices deste violento atentado". ${ }^{69}$

Nota-se que, até aqui, o campo móvel de tensões desencadeado pelos alvarás de 1761 e 1773, bem como pelos avisos de 1767, 1776, 1788 e 1800 , tendeu a favorecer tanto a escravos como a senhores. Contudo, se nota diferença importante entre os últimos: os pareceres em todas as instâncias da justiça pareciam ser mais favoráveis a reinóis que a senhores radicados na América portuguesa. Embora o aviso de 1788

68 Requerimento do preto de Nação de Angola, Caetano, por seu procurador João Garcia, à rainha D. Maria I, pedindo que se faça justiça quanto ao seu direito de estar forro e que ordene ao Governo da capitania de Pernambuco a verificação das injustiças cometidas contra ele pelo seu ex-dono, o cirurgião Jacinto de Campos Brito, 26/04/1799, AHU-PE, cx. 207, doc. 14120.

69 Requerimento do preto de Nação de Angola, Caetano, por seu procurador João Garcia, à rainha D. Maria I, 26/04/1799, op. cit. 
proibisse armadores reinóis de empregar marinheiros escravos em seus navios, contornou-se tal limitação legal por efeito da locação de cativos pertencentes a senhores radicados em Angola ou no Brasil. O processo envolvendo os marinheiros escravos Miguel Pinto Gaspar Mendes "e outros homens pretos" contra José Antônio Pereira, é um exemplo dessa situação particular - o qual, aliás, teve resultados funestos para a marujada. ${ }^{70}$ Pelo que pudemos apurar, José Antônio Pereira, Cavaleiro Professo da Ordem de Cristo, era um comerciante da praça de Lisboa que, entre as décadas de 1786 e 1810 senhoreava cerca de 10 navios, os quais conectavam os portos do Rio Janeiro, Recife, Salvador, Santos e Belém, na América portuguesa, da Costa da Mina, de Luanda e de Benguela, na África, de Montevidéu e Cumaná, na América espanhola, de Lisboa e "da Grã-Bretanha", na Europa, e de Bengala, na Índia. ${ }^{71}$ Assim, nota-se outra disposição no campo móvel de tensões quando indivíduos desse grupo social - que, como destacou Jorge Pedreira, distinguiram o "retalho" do "grosso trato" e não deixaram as atividades mercantis após adquirirem importantes títulos de nobreza - eram confrontados por escravos marinheiros. ${ }^{72}$ Por outro lado, Miguel Pinto Gaspar Mendes e os demais marinheiros escravos não pertenciam a José Antônio Pereira, mas, antes, eram apenas alugados por ele: seu senhor era Antônio de Souza Portela, "morador em Angola". Assim, nota-se um circuito complexo que envolvia escravos marinheiros residentes em Angola, matriculados

70 Certidão declarando a sentença da ação de proclamação da liberdade de alguns homens pretos que chegaram a Portugal, embarcados no porto de Pernambuco muitos anos depois da lei de 1761 e do aviso de 1776, 11/04/1778, AHU-PE, cx. 129, doc. 9759.

71 As embarcações que the foram atribuídas nessa breve amostragem foram os Navio Nossa Senhora da Conceição e Senhor Jesus dos Navegantes, Bergantim Nossa Senhora do Monte do Carmo, Chalupa Dois Amigos, Corveta Correio de Angola, Navio Cleópatra, Navio Esperança, Navio Fênix, Navio Santo Antônio de Lisboa, Navio São José, Navio São José Indiano. Ver Lisboa, 1786, ANTT, Feitos Findos, Juízo da Índia e Mina, cx. 193, n. 2, maço 6; 20/01/1794, AHU-PA, cx. 104, doc. 8197; 16/03/1801, AHU-RJ, cx. 191, doc. 24; 21/10/1801, AHU-RJ, cx. 195, doc. 39; 16/06/1803, AHU-RJ, cx. 202, doc. 27; 24/05/1803, AHU-RJ, cx. 207, doc. 39; 28/11/1804, AHU-RJ, cx. 36, doc. 2905; 16/08/1805, AHU, Montevidéu, cx. 1, doc. 15; 29/08/1806, AHU, Montevidéu, cx. 38, doc. 3041; 12/12/1806, AHU, Montevidéu, cx. 1, doc. 26; 04/08/1807, AHU-RJ, cx. 241, doc. 4; 12/1808, AHU-RJ, cx. 306, doc. 79; 13/08/1810, AHU-RJ, cx. 308, doc. 93; 03/06/1812, AHU-RJ, cx. 302, doc. 1; 03/06/1812, AHU-RJ, cx. 302, doc. 1.

72 Jorge M. Pedreira, "Os negociantes de Lisboa na segunda metade do século XVIII: padrões de recrutamento e percursos sociais", Análise Social, v. 27, n. 2-3 (1992), pp. 407-440. 
em Pernambuco e embarcados em navio pertencente a um poderoso comerciante de grosso trato de Lisboa.

Ao mesmo tempo, o caso dos escravos liderados por Miguel Pinto Gaspar Mendes contra seu poderoso locador lisboeta acena para um quadro mais amplo, no qual a historiografia recente tem patinado: referimo-nos às polarizações entre as relações "entre o Brasil e a economia europeia" - como se formula nas obras de Caio Prado Jr. e Fernando Novais ${ }^{73}$ - e o realce das "dinâmicas intra-coloniais" - como se apreende nas obras de Manolo Florentino, Luís Felipe de Alencastro e Roquinaldo Ferreira. ${ }^{74}$ Nesses modelos de análise, são destacados ora o conceito de "comércio triangular", como se percebe nas obras de Prado Jr. e Novais, ora a "bipolaridade do tráfico sul-sul", como sublinham Florentino, Alencastro e Ferreira. Sem embargo, o caso de José Pereira da Silva e de outros grandes comerciantes baseados em Lisboa na segunda metade do século XVIII acena para um enquadramento que remete àquilo que convém chamar de economia mundial. ${ }^{75}$ Afinal, esses grandes comerciantes lisboetas da segunda metade do século XVIII participavam do tráfico de escravos entre a África e a costa do Brasil, comercializavam livremente, à época, no âmbito de outros impérios coloniais, como o espanhol, e frequentavam portos asiáticos, como os de Bengala e da Costa de Malabar, em busca de produtos, mormente tecidos, que podiam ser trocados em todos os portos do Atlântico - sobretudo por escravos. Assim, é possível apreender no mundo empírico um tipo de relação social e de poder recorrente nas lides marítimas nos anos aqui em consideração: aquela

73 Caio Prado Júnior, Formação do Brasil contemporâneo, São Paulo: Brasiliense, 1986; Fernando A. Novais, Portugal e Brasil na crise do antigo sistema colonial, São Paulo: Hucitec, 1995.

74 Manolo Florentino, Em costas negras: uma história do tráfico de escravos entre a África e o Rio de Janeiro (Séculos XVIII e XIX), São Paulo: Cia. das Letras, 1997; Luiz Felipe de Alencastro, O trato dos viventes: formação do Brasil no Atlântico Sul, São Paulo: Companhia das Letras, 2000; Roquinaldo Ferreira, "Dinâmica do comércio intra-colonial: Geribitas, panos asiáticos e guerra no tráfico angolano de escravos (século XVIII)", in João Fragoso; Maria F. Bicalho; Maria de F. Gouvêa (orgs.), O antigo regime nos trópicos. A dinâmica imperial portuguesa: séculos XVI-XVIII (Rio de Janeiro: Civilização Brasileira, 2001), pp. 339-377.

75 Braudel, Civilização material, pp. 11-74; Wallerstein, The Modern World-System, pp. 300-346; Dale W. Tomich, "Atlantic History and World Economy: Concepts and Constructions", Proto Sociology, v. 20 (2004), pp. 102-121; Maximiliano M. Menz e Gustavo Acioli, "Resgate e mercadorias: uma análise comparada do tráfico luso-brasileiro de escravos em Angola e na Costa da Mina (século XVIII)", Afro-Ásia, n. 37 (2008), pp. 43-73. 
em que grandes comerciantes e armadores residentes em Lisboa tornavam-se proprietários, ou locadores, de escravos marinheiros em geral adquiridos diretamente na África, levando-os, através de seus navios, por múltiplos entrelaçamentos de rotas e conexões através do Atlântico e do Índico. Predominava, então, algo bem mais amplo que um mero "comércio triangular" ou uma "bipolaridade sul-sul": o próprio tráfico de escravos sempre envolveu mercadorias asiáticas, e numa proporção que parecia ir muito além do peso frequentemente atribuído às mercadorias coloniais. $^{76}$

Uma vez que a primeira instância das ações cíveis de libelo baseadas no alvará de 1761 era a ouvidoria da alfândega, sabemos que o processo dos marinheiros escravos liderados por Miguel Pinto Gaspar Mendes percorreu um longo caminho até a Suplicação de Lisboa, sendo seus sucessivos despachos recorrentemente contestados por uma das partes - a do locador, o comerciante de grosso trato, José Antônio Pereira. ${ }^{77}$ A "sentença proferida nos autos", de abril de 1778, inserida no processo, está materializada num “Acórdão", cujos assinantes são três magistrados da Casa de Suplicação, sendo um deles João Ferreira Ribeiro de Lemos. ${ }^{78}$ O "Acórdão" tem como ponto de partida um aspecto importante contido no alvará de 1761, qual seja, o "benefício da expedição da Navegação e Comércio". Considerando este ponto específico, os argumentos esposados pelos escravos marinheiros "contra José Antônio Pereira", na forma de "uma ação de proclamação de liberdade, por chegarem a este Reino embarcando-se no porto de Pernambuco, muitos anos depois da publicação da Lei de 19 de setembro de 1761 e sem se verificarem os requisitos do Aviso de 22 de fevereiro de 1776", não pareceram suficientes aos desembargadores. Conforme escreveram no "Acórdão", o "réu se defende com a matéria da sua conversação, que provou com documentos,

76 Menz e Acioli, "Resgate e mercadorias", pp. 43-73.

77 Certidão declarando a sentença da ação de proclamação da liberdade de alguns homens pretos que chegaram a Portugal, 11/04/1778, op. cit.

78 Carta de João Ferreira Ribeiro de Lemos, Corregedor do Cível da Corte, 14/05/1776, ANTT, Registo Geral de Mercês de D. José I, livro 14, fl. 90v; João Ferreira Ribeiro de Lemos Desembargador dos Agravos, 07/05/1779, ANTT, Registo Geral de Mercês de D. Maria I, livro 6(2), fl. 177. 
e testemunhas". ${ }^{79}$ Assim, os desembargadores sentenciavam em face "dos autos e disposições de Direito", que "o caso do presente processo" não estava entre aqueles "que as Leis recomendam se julguem em dúvida a favor da liberdade". Portanto, estavam vetadas interpretações que considerassem a "validade ou nulidade de alguma manumissão que se deve aos autores por seu verdadeiro senhor", bem como "da perplexidade de conhecimento da vontade do senhor quando em alguma disposição, ou testamento dá a liberdade ao seu escravo e ao mesmo tempo dispõe dele". Definitivamente, afirmam os desembargadores, não se tratava aqui desses "exuberantes privilégios da liberdade", ${ }^{80}$

Ao mesmo tempo, os desembargadores argumentaram que em nenhum momento se comprova que "os autores vieram a este porto para cá ficarem servindo", bem como que outorgar-lhes a liberdade "resultaria num notável prejuízo ao Reino e sua Capital dificultando-se o comércio que a ela quisessem dirigir os habitantes das Conquistas que geram o seu negócio em navios próprios, ou alheios, e com escravos seus, ou alugados". Ademais, a configuração sistêmica e mundial da escravidão marítima também contribuiu para a reiteração do cativeiro de Miguel Pinto Gaspar Mendes e de seus camaradas de convés, uma vez que parecia aos desembargadores que faltava "também outro requisito essencial por Direito para a poderem intentar, qual é a prestação das contas que primeiro devem dar a seu senhor do emprego, administração, ou ministério, a que fossem por ele destinados". Caso não se respeitasse este preceito básico, observam os desembargadores, "podem acontecer prejuízos graves ao mesmo senhor, que nem ao menos foi achado ou ouvido", o que iria "contra os princípios de todo o Direito, ainda natural". Assim, a causa dos escravos marinheiros seria, nesse caso, uma "contravenção da Lei, e não de favor da liberdade". Diante desse circuito complexo, e respeitando-se antes de tudo a propriedade sobre o escravo, parecia fácil argumentar que seu senhor, Antônio de Souza Portela, morador em Luanda, não teria sido achado ou informado dos termos do processo.

79 Certidão declarando a sentença da ação de proclamação da liberdade de alguns homens pretos que chegaram a Portugal, 11/04/1778, op. cit.

80 Certidão declarando a sentença da ação de proclamação da liberdade de alguns homens pretos que chegaram a Portugal, 11/04/1778, op. cit. 
E, com efeito, egressos de Angola, onde viviam, embarcados em Pernambuco, na América portuguesa, e demandando suas ações de liberdade em Lisboa, os escravos marinheiros liderados por Miguel Pinto Gaspar Mendes achavam-se enredados numa estrutura de navegação dotada de um grande poder de constrangimento em decorrência de suas enormes distâncias - tanto geográficas, como sociais. ${ }^{81}$

Um argumento capital formulado pelos desembargadores selou o destino dos marinheiros escravos de uma vez por todas. Conforme o "acórdão", a "matrícula de Pernambuco" dispunha de "cláusula substancial" relativamente ao emprego daqueles indivíduos a bordo do navio pertencente a José Antônio Pereira, embora tivesse se omitido "a declaração dos nomes dos senhores dos escravos". O arrazoado que justificou essa falta - pois estava previsto na lei, como vimos, o necessário registro dos senhores dos escravos empregados como marinheiros nos navios -, considerou que "esta declaração é uma qualidade inerente, e acidental que se acha suprida pela geminada, e muitas vezes repetida confissão que os autores fazem de serem escravos, e ser seu senhor Antônio de Souza Portela morador em Angola". Assim, atribuindo aos próprios escravos o simples fato de admitirem serem escravos e de, portanto, pertencerem a um senhor específico, os desembargadores utilizaram esta declaração, por si só óbvia, para justificar o descumprimento da lei por seu locador do arrolamento de seu proprietário nos registros do porto do Recife. O simples fato de os escravos admitirem sua condição - aspecto indissociável, aliás, de sua demanda pela liberdade - constituía o fundamento pelo "qual se purifica a identidade das pessoas, a cujo fim só se dirige semelhante declaração". A sentença final foi, pois, peremptória e absolutamente prejudicial para os escravos marinheiros. Conforme os desembargadores, "os autores carecem da ação intentada, e devem ficar no estado de cativeiro em que se achavam quando aportaram a este Reino". Por sua vez, o "réu", isto é, José Antônio Pereira, estava livre para "navegar o navio com os oficiais, marinheiros, e serventes que trouxe, livremente até para observância das Leis, e Direito do Mar, que obriga os ditos oficiais e

81 Certidão declarando a sentença da ação de proclamação da liberdade de alguns homens pretos que chegaram a Portugal, embarcados no porto de Pernambuco muitos anos depois da lei de 1761 e do aviso de 1776. Lisboa, 11/04/1778, AHU-PE, op. cit. 
marinheiros a servir no mesmo navio até tornar ao porto de que saíram". Finalmente, o marinheiro escravo Miguel Pinto Gaspar Mendes e seus colegas marujos sofreram outro prejuízo que deveria afetar diretamente as soldadas que, porventura, recebessem dali por diante: "E paguem os autores os custos dos autos em que os condenam". ${ }^{82}$

Outro processo, em curso entre 1806 e 1810, envolveu mais uma vez o comerciante José Antônio Pereira. Contudo, ao contrário das dezenas de processos movidos contra ele por aqueles anos, essa "ação cível de libelo" tinha este comerciante como autor, ao passo que outro escravo marinheiro, Luís Pereira, nela aparece como réu. Nesse caso, o comerciante lisboeta não figura como locador, mas como proprietário do escravo marinheiro em questão, o qual é descrito no processo como um "homem preto", "escravo do autor" e marinheiro do navio São José Indiano - uma embarcação construída em Damão, na Costa de Malabar, Estado da Índia ${ }^{83}$ cujas deambulações entre os portos da América portuguesa, da América espanhola, da África, do Reino Unido e de Portugal estão registradas em diversas fontes documentais. Em inícios de 1804, por exemplo, o navio São José Indiano tinha partido de Lisboa para Cádiz "e dali para Vera Cruz, e de volta para um dos Portos de Inglaterra e Lisboa", o que significava que José Antônio Pereira participava dos circuitos comerciais internos ao império espanhol, ligando Cádiz ao vice-reinado da Nova Espanha e, depois, conectava-os com o mercado britânico. Por outro lado, em novembro de 1804, segundo seu passaporte, o mesmo navio partiu de Lisboa para "Angola, e dali para os Portos do Brasil, donde há de voltar para a mesma Cidade de Lisboa". ${ }^{84}$

Segundo o processo que seu senhor, José Antônio Pereira, movera contra ele, o escravo marinheiro Luís Pereira tinha feito três viagens seguidas no navio São José Indiano: saíra de Moçambique ao Maranhão

82 Certidão declarando a sentença da ação de proclamação da liberdade de alguns homens pretos que chegaram a Portugal, 11/04/1778, op. cit.

83 Requerimento do proprietário do navio São José Indiano, José Antônio Pereira, ao príncipe regente D. João, solicitando passaporte para a dita embarcação fazer viagem para os Estados do Brasil e dali para a Grã-Bretanha, s/d, AHU, Avulsos, cx. 302, doc. 1.

84 Passaporte do secretário de estado da Marinha e Ultramar, visconde de Anadia, D. João Rodrigues de Sá e Melo Meneses e Souto Maior, ao navio São José Indiano, de que é mestre Lourenço Perfeito e senhorio José Antônio Pereira, para fazer viagem para os portos do Brasil, 28/11/1804, AHU, Avulsos, cx. 302, doc. 129. 
e, de São Luís, tomara a direitura de Lisboa. Trata-se de rota peculiar: muito provavelmente, trouxera escravos de Moçambique, uma vez que, por estes anos, a capitania do Maranhão havia importado muitos indivíduos dessa procedência. ${ }^{85}$ Contudo, conforme a documentação compulsada, a rota feita pelo navio São José Indiano e pelo marinheiro escravo aqui em questão foi um pouco mais tortuosa. Conforme é possível apurar, o São José Indiano partiu do Maranhão em 18 de abril de 1806, chegando a Lisboa 57 dias depois, em 14 de junho do mesmo ano. Em sua carga, havia produtos tipicamente maranhenses: 1.004 sacas de algodão, 2.363 sacas de arroz, 100 "couros em cabelo", 1.405 "vaquetas," ou couro de vitela, 45 paneiros de goma e dois "embrulhos": um contendo cocos de babaçu e outro raízes de ipecacuanha. ${ }^{86}$ Quando o navio tocou o porto de Lisboa, o escravo marinheiro Luís Pereira fugiu para terra e, depois, requereu sua carta de liberdade ao administrador da alfandega de Lisboa - a qual, aliás, lhe foi concedida. Contudo, um alvará, daquele mesmo ano de 1806 cassou sua carta de liberdade. Certamente o escravo marinheiro apelou daquela decisão, razão pela qual o resultado final do processo foi apenas exarado em 29 de maio de 1810. Tal resultado foi, mais uma vez, favorável ao plenipotenciário comerciante escravista de Lisboa: conforme o despacho do escrivão da mesa do desembargo do paço, António Constantino Álvares Pereira, cabia ao escravo marinheiro Luís Pereira, dali por diante "reconhecer o autor por seu legítimo senhor e a prestar-lhe os seus serviços enquanto permanecer na escravidão" ${ }^{87}$

85 Emory Center for Digital Scolarship, "BDTTE".

86 Ofício do governador e capitão-general D. Francisco de Melo Manuel da Câmara para o secretário de estado da Marinha e Ultramar, visconde de Anadia, João Rodrigues de Sá e Melo Souto Maior, a remeter os mapas da carga e os conhecimentos do barril de arroz que levam os navios São José Indiano, Victória, o bergantim Bonfim e a escuna Indústria, 18/04/1806, AHU-MA, cx. 146, doc. 10551; Ofício do Juiz da Visita do Ouro, Pedro Duarte da Silva, ao secretário de estado da Marinha e Ultramar, visconde de Anadia, João Rodrigues de Sá e Melo Souto Maior, sobre a visita a galera Pernambucana, de que é capitão Bernardo José da Fonseca, vindo do Rio de Janeiro, e São José Indiano, de que é capitão José Lourenço Perfeito, vindo do Maranhão; informando os passageiros e remetendo mapas das cargas de madeiras, couros, café, tapioca, arroz, cacau, anil, açúcar, farinha e algodão, 14/06/1806, AHU, Avulsos, cx. 230 , doc. 34 .

87 Ação cível de libelo em que é autor José Antônio Pereira e réu Luís Pereira, "homem preto", escravo do autor e marinheiro do navio São José Indiano, 29/05/1810, ANTT, Feitos Findos, Juízo da Índia e Mina, maço 4, $\mathrm{n}^{\circ} 15$, cx. 324. As datas destes eventos são desencontradas. Nas anotações ao processo em questão, informa-se que o navio São José Indiano chegou ao porto de Lisboa vindo do Maranhão antes de março de 1806, e que a carta de liberdade de Luís 


\section{Conclusões}

À época das reformas pombalinas, as lutas entre as nobrezas de toga e de nascimento ensejaram um corpus legal que tendia a promover a primeira e a rebaixar as instituições exclusivistas da segunda. É por essa ótica que se compreende os alvarás e avisos que, entre 1761 e 1800, proibiram o tráfico de escravos e instituíram, a longo prazo, a abolição da escravidão em Portugal. Contudo, os resultados dessa legislação desencadearam processos não planejados, como as tensões entre escravos marinheiros, senhores e locadores, mediadas por indivíduos ligados aos órgãos monárquicos da governação e da justiça. Assim, portanto, a legislação em questão produziu um campo móvel, ou pendular, de tensões envolvendo grupos e indivíduos de distintos níveis sociais. Ao mesmo tempo, as ações cíveis de libelo perpetradas pelos escravos marinheiros, secundados por africanos e afrodescendentes livres e libertos de Lisboa, acenam para um quadro mais amplo dentro do qual se percebe o peso e a importância da escravidão marítima na reprodução do comércio e da navegação no império português. Alicerçada em padrões fundados ainda no mundo antigo, mormente no império romano, a escravidão marítima tendeu, no período moderno, a superar os limites do Mediterrâneo e a converter-se numa estrutura conectada com a expansão do mercado mundial. Finalmente, é fundamental ressaltar que, à medida que a legislação pombalina incorporou tendências então vigentes em toda Europa - as quais defendiam a exclusão da escravidão em seu solo e a reprodução desta instituição na América e, subsidiariamente, na África -, seus princípios disseminaram-se, embora mediante conflitos mais ou menos abertos, não apenas entre indivíduos do nível mais alto, mas também, e talvez sobretudo, entre escravos e libertos portugueses, bem como entre escravos provenientes do Brasil, mormente entre os que desempenhavam funções ligadas à marinharia.

Recebido em 07/07/2019 e aprovado em 22/12/2019

Pereira teria sido embargada em naquele mesmo mês e ano. Contudo, os registros de saída de São Luís e de chegada a Lisboa não corroboram essas informações, organizadas quatro anos depois daqueles eventos, isto é, 1810. Parece impossível que o navio em questão estivesse no porto de Lisboa em março e no de São Luís em 18 de abril do mesmo ano. 


\title{
Resumo
}

Analisamos neste artigo alvarás e avisos que, entre 1761 e 1800, proibiram o tráfico de escravos e, a longo prazo, encaminharam a abolição da escravidão em Portugal. Nossa ênfase recai sobre os escravos marinheiros que se dirigiam a Lisboa e sobre a legislação específica que lhes foi destinada. Discutimos, assim, mediante o exame de petições e peças processuais, as relações estabelecidas entre escravos marinheiros, senhores e locadores, bem como as relações entre estes indivíduos e funcionários de órgãos de justiça ligados à monarquia portuguesa. Argumentamos que no campo móvel de tensões ensejado pelas leis pombalinas - as quais refletiam, em última análise, as lutas entre a primeira e a segunda nobreza -, estas, a despeito de não se constituir num corpus legal abolicionista ou humanitário, tanto poderiam favorecer a senhores como a escravos.

Palavras-chave: escravos marinheiros - escravidão marítima - Império Português - leis pombalinas.

\begin{abstract}
In this article we analyze acts and decrees that, between 1761 and 1800, prohibited the slave trade and, in the long term, led to the abolition of slavery in Portugal. We focus on sailor slaves heading to Lisbon and the specific legislation intended for them. We thus discuss the relationships established between sailor slaves, their masters and lessors by examining petitions and procedural documents, as well as analyzing the relations between these individuals and officials of monarchy-bound justice organs. We argue that in the mobile field of tensions entailed by the Pombaline laws - which ultimately reflected the struggles between the first and second nobility -, such relationships, while not constituting an abolitionist or humanitarian legal corpus, could either favor to masters like slaves.
\end{abstract}

Keywords: sailor slaves - maritime slavery - Portuguese Empire - Pombaline laws. 